\title{
Analysis of fermented liquid fertilizer from marine crab waste
}

\author{
T. Ramesh ${ }^{1, *}$, A. Amuthavalli and R. Boopathy ${ }^{3}$
}

PG \& Research Department of Biotechnology, Hindustan College of Arts \& Science, Padur, Kelambakkam, Chennai, India

* Corresponding author

\begin{abstract}
Soil is the main source of supplying essential nutrients for plant growth. In agricultural practice, when a particular nutrient or a group of nutrients are absent in the soil, it may affect the growth of the plant. Thus, most of the farmers practicing to apply chemical fertilizers to overcome the soil nutrient deficiency. Chemical fertilizers enhance the soil fertility on one hand whereas on the other hand it cause environmental pollution. Therefore alternative methods of soil nutrition practice must be considered. Hence this work focused to prepare fermented liquid fertilizer to enhance the plant growth. In the present study the fermented liquid fertilizer was prepared by fermenting the Portunussanguinolentus (Herbst, 1783) crab wastes with jaggery. After 15 days, the fermented liquid from crab waste was filtered and used for further study. The harvested liquid subjected to physico chemical and microbial analysis. The functional group and active compounds present in the fermented liquid was analyzed through FT-IR and GC-MS study. Phytotoxicity of the fermented liquid was determined through seed germination assay by using TMV-7 ground nut seeds. The result showed that the fermented liquid was diluted in water in the ratio of 1:100 exhibited higher seed germination when compared to other test dilutions and control. Thus the present work strongly supports the view that the traditionally fermented crab waste liquid contain high nutrients and active compounds and that may support the ground nut plant growth.
\end{abstract}

Keywords-Liquid fertilizer, Fermented crab waste, FT-IR, GC-MS, seed germination assay.

\section{INTRODUCTION}

Nutrition is one of the most important factors to control agricultural productivity. Continuous agricultural practices diminish the nutrient content of the soil. Soil is the main source of supplying essential elements to plants. When a particular mineral or a group of minerals are absent in the soil, the plant will show deficiency symptoms and affect the physiological processes in plants including reproduction and growth(Sandip, 2011). To overcome the mineral deficiency and to increase the yield, the soil can be enriched by supplying these nutrients from external sources. The major compounds which are added into the soil to improve its fertility are grouped under two broad categories: (a) Chemical fertilizers and (b) Organic fertilizers. Most of the farmers fertilize the soil by adding chemical fertilizers due to their quick action in soil (Ann McCauley, 2009). Chemical fertilizers contains a large amount of the heavy metals like Mercury ( $\mathrm{Hg})$, Cadmium $(\mathrm{Cd})$, Arsenic (As), Lead $(\mathrm{Pb})$, Copper $(\mathrm{Cu})$ and Nickel $(\mathrm{Ni})$; natural radionuclide like Uranium $\left({ }^{238} \mathrm{U}\right)$, Thorium $\left({ }^{232} \mathrm{Th}\right)$, and Polonium $\left({ }^{210} \mathrm{Po}\right)$. Thus, application of chemical fertilizer leads to water, soil and air pollution.
(Sönmezet al., 2007). Chemical fertilizers enhance the crop yield on one hand whereas on the other hand act as environmental hazards. Therefore alternative methods of agricultural practice must be considered. Under present conditions, application of organic farming is much promising (Matson et al., 1997; Drinkwater et al., 1998; Tillman 1999; Zhu et al., 2000; Reganoldet al., 2001; Xieet al., 2003). Organic farming is a method of agriculture practice in which farmers not use synthetic pesticides, fertilizers, genetically modified organisms and growth hormones. Organic farming will increase the agriculture production and makes a pollution free environment (Ramesh et al., 2005). Large quantities of wastes are generated in the processing of aqua foods from crustaceans and fishes. These materials contain appreciable amounts of nutrients to plants which may be useful for agriculture practices (MacLeod et al., 2006). Most aqua food processing waste was disposed of in landfill sites or applied haphazardly to land (Swanson et al., 1980; Muradoet al., 1994). Land application of crustacean waste is problematic and cause soil pollution. Hence these waste must be processed in alternate way.Dao \& Kim (2011), has 
reported the use of fermented fish waste products as liquid fertilizer and the nutrients in the fermented liquid fish waste may stimulates the growth of the plants through beneficial soil microorganisms present in it and increasing the uptake of essential nutrients. This fertilizer because of its liquid nature is readily available, releases the nutrients slowly and prevents leaching from the soil. Nutrients can be applied in the form of foliar sprays which immobilize and supplement the nutrients to the leaves. From the foregoing literature, it can be clearly understood that in order to manage the high amount of crustacean waste and it may be fermented and used as a liquid fertilizer for various agriculture practices and this would paves the way for sustainable development in agriculture.

\section{MATERIALS AND METHODS}

\subsection{Raw material collection \& processing}

The discarded part of the processed marine crabs were collected from the fish market at Kelambakkam -603103. The collected waste mainly consisting of the carapace, intestines and other discarded part of the three-spot swimming crab, Portunussanguinolentus (Herbst, 1783). The collected crab waste was washed in chlorine free water for fermentation process

\subsection{Preparation of fermented liquid fertilizer}

Liquid fertilizer was prepared in traditional way based on the procedure described by ThendralHepsibha B. \&Geetha A. (2019). According to that procedure $1.5 \mathrm{~kg}$ of native jaggery, $1 \mathrm{~kg}$ of crab waste and 5 liters of chlorine free water were added inside the clay pot and mixed thoroughly. The mouth of the pot was covered with a cotton cloth to prevent the entry of flies. After 14 days, the fermented materials were filtered by using cotton cloth and the filtrate was subjected to further analysis.

\subsection{Analysis of physico-chemical parameters}

The filtered liquid fertilizer was subjected to physical parameters like Color, Odor, pH, Electrical Conductivity. The chemical parameters such as Total Nitrogen (Kjeldahl), Total Phosphorous, Potassium, Sodium, Calcium, Magnesium, Sulphur, Zinc, Manganese, Iron and Copper were tested at NAF Research \& Development Centre, Anna University Taramani Campus, Chennai - 600 113, according to the procedure described by Tanden (1993). Heavy metals such as Mercury, Cadmium and Lead were determined by Atomic Absorption Spectroscopy method

\subsection{Microbial analysis}

The heterotrophic bacterial count, total coliform and fecal coliforms in fermented liquid were determined. For heterotrophic plate count, $1 \mathrm{ml}$ of the fermented liquid was diluted with $9 \mathrm{ml}$ of sterilized distilled water, then serially diluted and analyzed by standard plate count method. 0.5 $\mathrm{ml}$ of serially diluted samples were poured on petri plate contain nutrient agar medium and incubated at $35^{\circ} \mathrm{C}$ for 48 hours. Total bacterial counts are represented as $\log$ of colony forming units per $\mathrm{mL}$ of the fermented liquid (CFU/ml). Total coliform bacteria and fecal coliform bacteria were determined through multiple-tube fermentation technique and the results were expressed as $\log$ (MPN/ml) (Thendral Hepsibha \& Geetha 2017). All the experiments were replicated three times.

\subsection{FT-IR analysis}

Fourier Transform Infrared Spectrophotometer (FT-IR) is the most powerful tool for identifying the functional groups present in any compounds. In the present work functional group of the liquid fertilizer was analyzed in the range from 400 to $4000 \mathrm{~cm}^{-1}$ with a resolution of $4 \mathrm{~cm}^{-1}$ by using FT-IR spectrophotometer (Shimadzu, IR Affinity 1, Japan) (Sugumaret al., 2015).

\subsection{GC-MS analysis}

GC-MS analysis is performed to identify the active biomolecule present in the liquid fertilizer from fermented crab waste. For that the liquid fertilizer was injected into the instrument GC and MS JEOL GC mate equipped with secondary electron multiplier (Agilent Technologies $6890 \mathrm{~N}$ Network GC system for gas chromatography). The column (HP5) was fused silica $50 \mathrm{~m} \times 0.25 \mathrm{~mm}$ I.D. The study conditions were $20 \mathrm{~min}$. at $100^{\circ} \mathrm{C}, 235^{\circ} \mathrm{C}$ for column temperature at $3 \mathrm{~min}$ and $240^{\circ} \mathrm{C}$ for injector temperature, carrier gas was helium, and split ratio was 5:4. The $1 \mu \mathrm{l}$ of the sample was evaporated in a split-less injector at $300^{\circ} \mathrm{C}$ and the run time was $22 \mathrm{~min}$. The active biomolecule of the liquid fertilizer was identified by Gas Chromatography coupled with Mass Spectrometry and the result spectrum was analyzed using the NIST08 library (Radhakrishnanet al., 2017).

\subsection{Seed germination assay}

Seed germination assay was performed to determine the phyto-toxicity of the fermented liquid fertilizer. For this experiment the fermented liquid fertilizer was diluted in chlorine free water with the ratio of 1:200 $(5 \mathrm{ml} / 1000 \mathrm{ml})$, 1:100 (10 ml / $1000 \mathrm{ml}), 1: 50(20 \mathrm{ml} / 1000 \mathrm{ml}), 1: 25$ (40 $\mathrm{ml} / 1000 \mathrm{ml}$ ) and control (water alone). The ground nut seed (TMV-7) was soaked in liquid fertilizer for 24 hours. After the soaking period, 10 numbers of each ground nut 
seeds were placed in tissue paper sprinkle with liquid fertilizer. Now the seeds were incubated in room temperature for 72 hours(Muthezhilanet al., 2012\& 2014; Thendral Hepsibha \& Geetha 2019). After the incubation the germinated seeds were identified and the percentage of germination and percentage of Relative Seed Germination (RSG) were calculated by the following formula,

$$
\text { Germination \% }=\frac{\text { Number of Seeds Germinated }}{\text { Total Number of Seeds }} \times 100
$$

$$
\text { RSG } \%=\frac{\text { Number of seeds germinated in test sample }}{\text { Number of seeds germinated in control }} \times 100
$$

\section{RESULTS \& DISCUSSION}

\subsection{Analysis of physico-chemical parameters}

The objective of physico-chemical analysis was to identify the nutrient content of the fermented liquid and to determine its suitability for agriculture purpose. The color of the fermented liquid was light golden yellow color and it produced fruity odor at the time of harvest. The results of physico-chemical analysis were presented in Table 1. Heavy metals such as Mercury $(\mathrm{Hg})$, Cadmium (Cd) and Lead $(\mathrm{Pb})$ content of the organic fermented liquid was analyzed (Table 1).

\begin{tabular}{|c|c|c|c|}
\hline S. No & Parameters & Unit & Result \\
\hline \multicolumn{4}{|c|}{ Physical parameters } \\
\hline 1. & $\mathrm{pH}$ & & $5 \pm 0.01$ \\
\hline 2. & $\begin{array}{l}\text { Electrical } \\
\text { conductivity }\end{array}$ & $\mu \mathrm{S} / \mathrm{cm}$ & $11623 \pm 1.45$ \\
\hline \multicolumn{4}{|c|}{ Chemical parameters } \\
\hline 3. & $\begin{array}{l}\text { Total Nitrogen } \\
\text { (Kjeldahl) }\end{array}$ & $\%$ & $0.21 \pm 0.008$ \\
\hline 4. & $\begin{array}{l}\text { Total Phosphate as } \\
\mathrm{P}_{2} \mathrm{O}_{5} \#\end{array}$ & $\%$ & $0.41 \pm 0.01$ \\
\hline 5. & Potassium as $\mathrm{K}_{2} \mathrm{O} \#$ & $\%$ & $0.27 \pm 0.003$ \\
\hline 6. & Sodium as $\mathrm{Na} \#$ & $\mathrm{mg} / \mathrm{kg}$ & $1500 \pm 1.15$ \\
\hline 7. & Calcium as $\mathrm{Ca} \#$ & $\mathrm{mg} / \mathrm{kg}$ & $5830 \pm 0.57$ \\
\hline 8. & Magnesium as Mg \# & $\mathrm{mg} / \mathrm{kg}$ & $1283 \pm 0.57$ \\
\hline 9. & Sulphur as $\mathrm{S} \#$ & $\mathrm{mg} / \mathrm{kg}$ & $282 \pm 0.88$ \\
\hline 10. & Zinc as $\mathrm{Zn} \#$ & $\mathrm{mg} / \mathrm{kg}$ & $9.64 \pm 0.008$ \\
\hline 11. & Manganese as Mn \# & $\mathrm{mg} / \mathrm{kg}$ & $17.33 \pm 0.01$ \\
\hline
\end{tabular}

Table.1: Physico-chemical characterization of fermented liquid on day 15 
Similar results were reported in Gunapaselam, that the total heterotrophic bacterial load was found to be $6.77 \pm 0.02$ (Thendral Hepsibha \& Geetha 2019), where as in the present work total bacterial load was recorded little high $(7.54 \pm 0.02)$. The total coliform count was recorded in the present work was $0.41 \pm 0.01 \log (\mathrm{MPN} / \mathrm{ml})$ and this count was little higher than total coliform count identified in Gunapaselam $(0.30 \pm 0.01 \log \mathrm{MPN} / \mathrm{mL})$ by Thendral Hepsibha \& Geetha 2019. There was no fecal coliforms identified in the fermented liquid and from these results, it understood that the fermented liquid harvested marine crab waste at 14th day was free of harmful and pathogenic microorganisms.

\subsection{FT-IR analysis}

The FT-IR results of the fermented liquid was presented in Table 3 and Figure 1.The graph showed the strong peaks for Alkynes $(\mathrm{C}=\mathrm{C})$, Amides $(\mathrm{N}-\mathrm{H})$, Carboxylic derivatives \&Arenes $(\mathrm{C}=\mathrm{C})$ and weak \& medium peaks for amines.

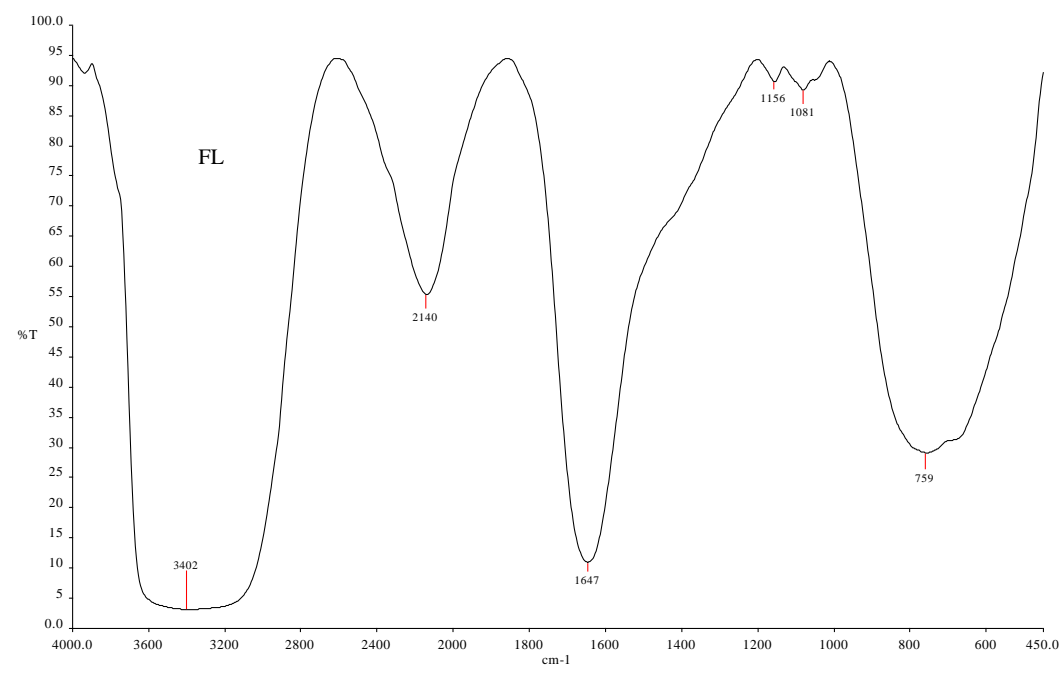

Fig.1: FT-IR graph of fermented liquid on day 15

Table 3: FT-IR interpretation of fermented liquid on day 15

\begin{tabular}{|c|c|c|c|c|c|}
\hline S. No & Transmittance $\%-\mathrm{T}$ & $\begin{array}{c}\text { Functional } \\
\text { group }\end{array}$ & Intensity & $\begin{array}{l}\text { IR frequency } \\
\text { Range } \mathbf{c m}^{-1}\end{array}$ & Types of bond \\
\hline 1. & 3402 & $\begin{array}{l}\text { Amine } \\
(\mathrm{N}-\mathrm{H})\end{array}$ & Weak & $3400-3500$ & Stretching vibrations \\
\hline 2. & 2140 & $\begin{array}{l}\text { Alkynes } \\
(\mathrm{C}=\mathrm{C})\end{array}$ & Strong & $2100-2250$ & \\
\hline 3. & 1647 & $\begin{array}{l}\text { Amides } \\
(\mathrm{N}-\mathrm{H})\end{array}$ & Strong & $1630-1695$ & Stretching vibrations \\
\hline 4. & 1156 & $\begin{array}{l}\text { Carboxylic } \\
\text { derivatives }\end{array}$ & Strong & $1100-1735$ & Stretching vibrations \\
\hline 5. & 1081 & $\begin{array}{l}\text { Amines } \\
(\mathrm{N}-\mathrm{H})\end{array}$ & Medium & $1000-1250$ & Stretching vibrations \\
\hline 6. & 759 & $\begin{array}{l}\text { Arenes } \\
(\mathrm{C}=\mathrm{C})\end{array}$ & Strong & $690-900$ & Bending vibration \\
\hline
\end{tabular}


The FT-IR spectroscopic technique is used to determine the degradation of polysaccharides, polypeptides, aliphatic, phenolic and carboxylic groups. Ravindra net al., (2013) reported that the FT-IR spectroscopic analysis of fermented animal fleshing composted with vermicomposting revealed that the appearance of Carboxylic groups and relative reduction in $\mathrm{CH}_{3}$ and $\mathrm{CH}_{2}$ groups which indicated the organic waste mineralization. In the present study reported that there was an appearance of carboxylic groups which could confirm the mineralization process took place completely during fermentation.

\subsection{GC-MS analysis}

The GC-MS analysis of fermented liquid fertilizer exhibit the presence of nine bioactive compounds (Table $4 \&$ Figure 2). Based on the retention time and peak value the biomolecules present in the fermented liquid was confirmed. The bioactive compounds present in the fermented liquid fertilizer were 3-Methylene-1,6heptadiene Phenol, 3-methyl, Phenol,2- ethyl, 3Pentadecanone, E,E-6,8-Tridecadien-2-ol, acetate, Undecane, Benzeneacetic acid, alpha,3-bis(acetyloxy)-5methoxy-, methyl ester, Furfural and 2-Heptanone.

Table 4: Compounds identified in the fermented liquid by using GC-MS

\begin{tabular}{|l|l|l|l|l|}
\hline S. No & $\begin{array}{l}\text { Retention } \\
\text { time }\end{array}$ & Compound name & $\begin{array}{l}\text { Molecular } \\
\text { formula }\end{array}$ & $\begin{array}{l}\text { Molecular } \\
\text { weight }\end{array}$ \\
\hline 1. & 15.93 & 3-Methylene-1,6- heptadiene & $\mathrm{C}_{10} \mathrm{H}_{16}$ & $136.238 \mathrm{~g} / \mathrm{mol}$ \\
\hline 2. & 16.55 & Phenol, 3-methyl & $\mathrm{C}_{17} \mathrm{H}_{21} \mathrm{NO}_{2}$ & $271.36 \mathrm{~g} / \mathrm{mol}$ \\
\hline 3. & 17.52 & Phenol,2- ethyl & $\mathrm{C}_{9} \mathrm{H}_{13} \mathrm{NO}$ & $151.209 \mathrm{~g} / \mathrm{mol}$ \\
\hline 4. & 18.32 & 3-Pentadecanone & $\mathrm{C}_{15} \mathrm{H}_{30} \mathrm{O}$ & $226.404 \mathrm{~g} / \mathrm{mol}$ \\
\hline 5. & 18.95 & E,E-6,8-Tridecadien-2-ol, acetate & $\mathrm{C}_{15} \mathrm{H}_{26} \mathrm{O}_{2}$ & $238.37 \mathrm{~g} / \mathrm{mol}$ \\
\hline 6. & 20.15 & Undecane & $\mathrm{C}_{11} \mathrm{H}_{24}$ & $156.313 \mathrm{~g} / \mathrm{mol}$ \\
\hline 7. & 23.33 & $\begin{array}{l}\text { Benzeneacetic acid, alpha,3-bis(acetyloxy)-5- } \\
\text { methoxy-, methyl ester }\end{array}$ & $\mathrm{C}_{14} \mathrm{H}_{16} \mathrm{O}_{7}$ & $296.27 \mathrm{~g} / \mathrm{mol}$ \\
\hline 8. & 13.07 & Furfural & $\mathrm{C}_{5} \mathrm{H}_{4} \mathrm{O}_{2}$ & $96.085 \mathrm{~g} / \mathrm{mol}$ \\
\hline 9. & 14.85 & 2-Heptanone & $\mathrm{C}_{7} \mathrm{H}_{14} \mathrm{O}$ & $114.188 \mathrm{~g} / \mathrm{mol}$ \\
\hline
\end{tabular}

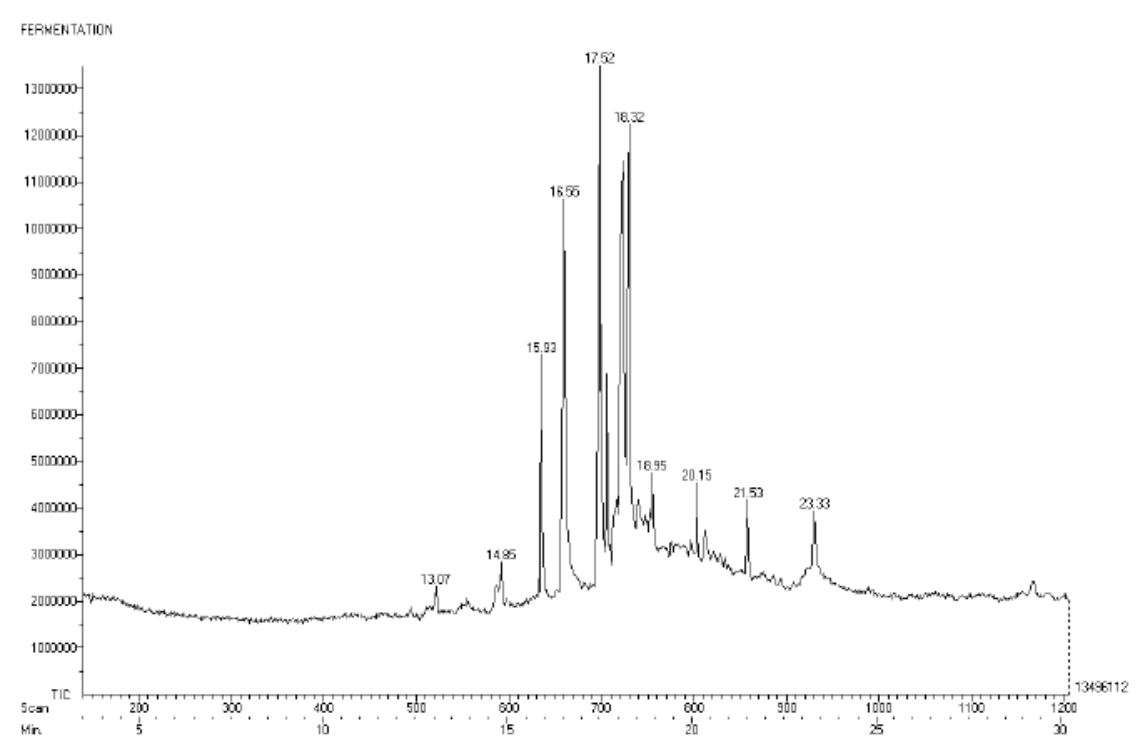

Fig.2: GC-MS graph of fermented liquid on day 15

Furfural $\left(\mathrm{C}_{4} \mathrm{H}_{3} \mathrm{OCHO}\right)$ is anorganic, colorless liquid and it is a dehydrated sugar product. The hydrogenated furfural products are used as a solvent in herbicide formulations in agriculture. The chemical compound 2-Heptanone is a colorless or white liquid ketone. It has banana-like fruity odor (https://pubchem.ncbi.nlm.nih.gov/compound/8051). 
This may be the reason that the liquid fertilizer at 14th day exhibit fruity smell. The other products are the by-product of the mineralization and polymerization of crab waste.

\subsection{Seed germination assay}

Fermented liquid fertilizer from marine crab waste is found to be rich in minerals and plant nutrients, but application of this fermented liquid in soil or plants has some limitations. Because, some of the products like ammonia, amino acids and organic acids etc., released during fermentation may act as a toxic to plants and native microorganisms of the soil. Zucconiet al., (1981) also reported that the application of partially degraded organic waste in to soil leads to high microbial activity and cause the soil oxygen depletion and arrest the nitrogen availability of the soil. In view of that the present work the phytotoxic effect of the fermented liquid was determined at different dilutions and compared with control (Table 5). In this work percentage of seed germination and Relative Seed Germination (RSG) were recorded high in 1:100 dilution (80\%) when compared to control $(70 \%)$ whereas percentage of germination and RSG were equal to control at lowest dilution (1:200). In contrast the percentage of germination and RSG were decreased by increasing concentrations of fermented liquid, it may due to higher $\mathrm{pH}$ and mineral content of the fermented liquid. Thus the idea of reusing the marine crab waste as a liquid fertilizer through simple conventional fermentation technique used to mitigate the environmental pollution and it may help to prevent the loss of soil nutrients.

Table 5: Results of seed germination assay

\begin{tabular}{|l|c|c|c|c|c|}
\hline S. No. & Test & Total seed & Germinated seed & Seed germination $(\%)$ & RSG $(\%)$ \\
\hline 1. & Test 1 $(1: 200)$ & 10 & $7 \pm 0.33$ & 70 & 100 \\
\hline 2. & Test 2 $(1: 100)$ & 10 & $8 \pm 0.57$ & 80 & 114.28 \\
\hline 3. & Test 3 $(1: 50)$ & 10 & $4 \pm 0.33$ & 40 & 57.14 \\
\hline 4. & Test 4 $(1: 25)$ & 10 & $3 \pm 0.33$ & 30 & 42.85 \\
\hline 5. & Control $\left(\mathrm{H}_{2} \mathrm{O}\right)$ & 10 & $7 \pm 0.33$ & 70 & \\
\hline
\end{tabular}

Data are expressed as Mean \pm SEM (Standard Error Mean)

RSG: Relative Seed Germination

\section{CONCLUSION}

The present work proves that marine crab waste can be fermented conventionally by using native jaggery without adding catalytic enzymes and it also confirm that conventional fermentation is a suitable method to biotransform the marine crab waste into nutrient rich liquid fertilizer. The bacterial load of the fermented liquid revealed that the bio conversion is carried out by their action. The maturity and goodness of the fermented liquid is confirmed through FT-IR and GC-MS analysis. The in vitro seed germination assay confirms that the fermented liquid from marine crab waste (ratio of 1:100) is suitable for agriculture use.

\section{ACKNOWLEDGEMENTS}

We would like to thank Sophisticated Analytical Instrument Facility (SAIF), Indian Institute of Technology Madras (IITM), Chennai-600 036, for FT-IR and GC-MS analysis and National Agro Foundation - Research \& Development Centre, Anna University Taramani Campus,
Chennai - 600113 for testing the physico-chemical parameters of the fermented liquid.

\section{REFERENCES}

[1] Ann McCauley (2009). Plant nutrient functions and deficiency and toxicity symptoms. Published by Montana State University-Bozeman, Bozeman, MT 59717. pp. 9945132.

[2] Dao V.T. and Kim J.K. (2011). Scaled-up bioconversion of fish waste to liquid fertilizer using a $5 \mathrm{~L}$ ribbon-type reactor. J. Environ. Managem., 92, 2441-2446.

[3] Drinkwater L.E., Wagoner P. and Sarrantonio M. (1998). Legume-based cropping systems have reduced carbon and nitrogen losses. Nature, 396, 262-65.

[4] Jwan J Abdullah, Darren Greetham, Chenyu Du, Gregory A. Tucker, P. (2020). Viability of Municipal Solid Waste as a source for Bioenergy products production. Inter. J. Environ. Agri. Biotech., 5(2), 310-341.

[5] Matson, P.A., Patron, W.J., Power, A.G. and Swift, M.J. (1997). Agricultural intensification and ecosystem properties. Science, 277, 504-9.

[6] MacLeod J.A., Kuo S., Gallant T.L. and Grimmett M. (2006). Seafood processing wastes as nutrient sources for crop production. Can. J. Soil Sci., 86, 631-40. 
[7] Murado M.A., Siso I.G., Gonzalez P. and Montemayor I. (1994). A simple form of immobilization and it effects on morphologic trends and metabolic activity of pellet-forming microfungi. Bioresour. Technol., 48, 237-43.

[8] Muthezhilan R., Jayaprakash K., Parthiban C. and AjmathJaffarHussain A. (2014). Plant Growth Promoting Effect of Seaweeds Collected from East Coast of Tamil Nadu, India. Biosci. Biotech. Res. Asia, 11(1), 53-58.

[9] Muthezhilan R., Sindhuja B.S., JaffarHussain A. and Jayaprakashvel M. (2012). Efficacy of Plant Growth Promoting Rhizobacteria Isolated From Sand Dunes of Chennai Coastal Area. Pakistan J. Biol. Sci., 15, 795-799.

[10] Radhakrishnan K., James F., Mohan A. and Chandra Mohan S. (2017). Gas chromatography and mass spectrometry analysis of Canthiumparviflorum leaves, Inno. J. Sci., 5(1), 22-27.

[11] Ramesh P., Mohan S. and Subba Rao A. (2005). Organic farming: Its relevance to the Indian context. Current Sci. (88), 561-68.

[12] Ravindran B., Sravani R., Mandal A.B., Contreras-Ramos S.M. and Sekaran G. (2013). Instrumental evidence for biodegradation of tannery waste during vermicomposting process using Eudriluseugeniae. J. Therm. Anal. Calorim. 111:1675-84

[13] Reganold J.P., Glover J.D., Andrews P.K. and Hinman H.R (2001). Sustainability of three apple production systems. Nature, 410, 926-29.

[14] Sandip D. (2011). Agricultural production and food distribution to vulnerable families in India today. The Financial Express. pp. 1-8.

[15] Sönmez İ., Kaplan M. and Sönmez S. (2007). An investigation of seasonal changes in nitrate contents of soils and irrigation waters in greenhouses located in antalyademre region. Asian J. Chem., 19, 5639-46.

[16] Sugumar S., Mukherjee A. and Chandrasekaran N. (2015). Eucalyptus oil nanoemulsion-impregnated chitosan film: antibacterial effects against a clinical pathogen, Staphylococcus aureus, in vitro. Int. J. Nanomedicine 10(1), $67-75$.

[17] Swanson G.R., Dudley E.G. and Williamson K.J. (1980). The use of fish and shellfish wastes as fertilizers and feed stuffs. pp. 281-327 in Bewick M.W.M. (ed). Handbook of organic waste conversion. Van Nostrand Reinhold Co., New York, NY.

[18] Tandon H.L.S. (1993). Methods of analysis of soils, plants, water and fertilizers, Fertilizer Development and Consultant Organization, New Delhi.

[19] ThendralHepsibha B. and Geetha A. (2017). Effect of fermented fish waste (Gunapaselam) application on the soil fertility with special reference to trace elements and the growth characteristics of Vignaradiata. Inter. J. Agri. Inno. Res., 5(4), 607-613.

[20] ThendralHepsibha B. and Geetha A. (2019). Physicochemical characterization of traditionally fermented liquid manure from fish waste (Gunapaselam). Indian J. Tradi. Knowl., 18(4), 830-836.
[21] Tillman, D. (1999). Global environmental impacts of agricultural expansion: then need for sustainable and efficient practices. Proceeding of the Natural Academy of Sciences USA, 96, 5995-6000.

[22] Xie B., Wang X., Ding Z. and Yang Y. (2003). Critical impact assessment of organic agriculture. J. Agri. Environ. Ethics., 16, 297-311.

[23] Zhu Y., Chen H., Fan J., Wang Y., Li Y., Chen J., Fan J.X., Yang S., Hu L., Leung H., Mew T.W., Teng P.S., Wang Z. and Mundt C.C. (2000). Genetic diversity and disease control in rice. Nature, 406, 718-22.

[24] Zucconi F., Pera A., Forte M. and De Bertoldi M. (1981). Evaluating toxicity of immature compost, Bio Cycle, 54-57.

[25] https://pubchem.ncbi.nlm.nih.gov/compound/8051 